\title{
Synthesis, Characterization and In Silico Study of Fe(III) Complex with N'-(4-Chlorobenzoyl)-Isonicotino-Hydrazide as Anti Tuberculosis Candidate
}

\author{
Ruswanto $^{1 *}$, Fajar Setiawan ${ }^{1}$, Nur Rahayuningsih ${ }^{1}$, Richa Mardianingrum ${ }^{2}$, \\ Nur Laili Dwi Hidayati ${ }^{1}$, Elsi Eryanti ${ }^{1}$ \\ ${ }^{1}$ Pharmacy department, STIKes Bakti Tunas Husada, Jl. Cilolohan No. 36, Kota Tasikmalaya, 46115, Indonesia \\ ${ }^{2}$ Pharmacy department, Universitas Perjuangan, J1. PETA No. 177, Kota Tasikmalaya, 46115, Indonesia \\ *Corresponding author: ruswanto@stikes-bth.ac.id
}

Received: July 2019; Revision: December 2019; Accepted: April 2020; Available online: May 2020

\begin{abstract}
The synthesis of Fe(III) complexes with ligands N'-(4-Chlorobenzoyl)isonicotinohydrazide can be synthesized through mixing metal and ligand dissolved in ethanol by reflux at $\pm 75^{\circ} \mathrm{C}$ for 5 hours. The instruments for the characterization of the complex were used UV-Visible and Infrared Spectrophotometry. The aims of the study are: to determine the synthesis method, characterize of the complex, and study the interaction of the complex with target receptors. The weight of the synthesized compound was obtained by $38.1 \mathrm{mg}$. The purity of the complex has been tested using the determination of melting point and got a melting point range was $196-198^{\circ} \mathrm{C}$. The maximum wavelength of $\mathrm{Fe}(\mathrm{III}) \mathrm{N}^{-}$-(4-Chlorobenzoyl)isonicotinohydrazid) complex was $261.0 \mathrm{~nm}$ and provide absorption of Fe-O vibrations at wavenumbers $530.42 \mathrm{~cm}^{-1}$. The docking process was done using AutodockTools-1.5.6 software which shows that the Fe(III)N'-(4-Chlorobenzoyl) isonicotinohydrazide complex can interact with Enoyl-Acyl Carrier Protein Reductase from Mycobacterium Tuberculosis and it has better interaction than isoniazid or N'-(4-Chlorobenzoyl)isonicotinohydrazide compound with the acquisition of free energy binding $(\Delta \mathrm{G})-9.80 \mathrm{kcal} / \mathrm{mol}$ and inhibition constant $(\mathrm{Ki}) 0.06529 \mu \mathrm{M}$.
\end{abstract}

Keywords: Synthesis, complex, Fe(III), isonicotinohydrazide, docking.

DOI: $10.15408 / j k v . v 6 i 1.11788$

\section{INTRODUCTION}

Recently, tuberculosis (TB) is still one of the world's public health problems that cause high morbidity and mortality. TB is a contagious infectious disease caused by the Mycobacterium tuberculosis (Kemenkes RI, 2016). Based on the World Health Organization (WHO), Indonesia is ranked $3^{\text {rd }}$ with the highest number of sufferers in the world after India and China (WHO, 2018). One of the most commonly used tuberculosis drugs is isoniazid. Isoniazid must be activated by KatG, a bacterial catalase-peroxidase enzyme in Mycobacterium tuberculosis. KatG catalyzes the formation of the isonicotinic acyl radical, which spontaneously couples with NADH to form the nicotinoyl-NAD adduct. This complex binds tightly to the enoyl-acyl carrier protein reductase InhA, thereby blocking the natural enoyl-AcpM substrate and the action of fatty acid synthase. This process inhibits the synthesis of mycolic acids, which are required components of the mycobacterial cell wall. Mycolic acid emptiness causes the structure of the cell wall to become weak and then broken so that mycobacteria die (Siswandono, 2016; Suarez et al., 2009; Timmins et al., 2004; Singh et al., 2008).

From the previous research that the N'(4-Chlorobenzoyl) isonicotinohydrazide has a free energy binding $(-6.644 \mathrm{kcal} / \mathrm{mol})$ and inhibition constant $(19.15 \mu \mathrm{M})$ better than isoniazid $(-4.64 \quad \mathrm{kcal} / \mathrm{mol} ; 398.64 \mu \mathrm{M})$ (Ruswanto et al., 2019). In another research, we have synthesis and in vitro test, some of the isonicotinohydrazide derivatives and they had been antibacterial activity and antituberculosis 
(Mardianingrum et al., 2019). From another research, the compound N'-(4-Chlorobenzoyl) isonicotinohydrazide has anti-bacterial activity, with a MIC (Minimum Inhibitory Concentration) value of $6.25 \mathrm{ppm}$ in Mycobacterium tuberculosis (Ruswanto et al., 2019). In comparison that the MIC for isoniazid $(0.1 \mu \mathrm{g} / \mathrm{mL})$, rifampicin $(0.5 \mu \mathrm{g} / \mathrm{mL})$ and ethambutol $(4.0 \mu \mathrm{g} / \mathrm{mL})$ (Suo et al., 1988).

In the study conducted by Mallikarjuna (2018) stated that the complex compound 2- (1H-indol-3-yldiazenyl)-4,5,6,7tetrahydro-1,3-benzothiazole synthesized showed potential antimicrobial activity against the pathogen tested. Its antimycobacterial activity showed higher than the free ligand.

The complex of 3-aminoquinoxaline2-carbonitrile N1, N4-dioxide with Fe (III) metal showed good results because this complex showed bacteriostatic or bactericidal activity in vitro in Mycobacterium tuberculosis as the causative agent of tuberculosis, the results of this synthesis show a higher inhibitory effect than therapeutic therapy drugs (Tarallo et al., 2010). The isoniazid complex with several metals shows that they can inhibit mycobacterial growth better than its free ligand (Ali et al., 2017).

Based on the above background, the development of antituberculosis drugs was performed by modifying the isoniazid derivative, namely the synthesis of the $\mathrm{N}$-(4-Chlorobenzoyl) isonicotinohydrazide with Fe (III) metal (Sousa et al., 2011).

\section{MATERIALS AND METHODS Instruments}

The instruments used in this research were Melting point apparatus, UV-Vis spectrophotometer Genesys 10S, Perkin Elmer Spectrum 100 FT-IR Spectrometer. Hardware and software equipment. The device used is a Samsung Laptop with Intel (R) Celeron (R) CPU $847 @ 1.10 \mathrm{GHz}$ RAM 2.00 GB 64-bit RAM, Marvin Sketch 5.2, AutodockTools1.5.6, Discovery Studio Visualizer, and PreADMET.

\section{Materials}

In this research, we used N'-(4-Chlorobenzoyl)isonicotinohydrazide, ethanol p.a, $\mathrm{FeCl}_{3} \cdot 6 \mathrm{H}_{2} \mathrm{O}$ p.a, hydrochloric acid p.a, aquadest, DMSO (Dimethyl sulfoxide), free ligand structure, ligand structure N'-(4Chlorobenzoyl) isonicotinohydrazide, the structure of the ligand complex Fe (III) (N'-(4Chlorobenzoyl)isonicotinohydrazide, and Enoyl-Acyl Carrier Protein Reductase enzyme with PDB code 2 X23.

\section{Synthesis of Fe (III) N'-(4-Chlorobenzoyl) isonicotinohydrazide Complex}

The N'-(4-chlorobenzoyl) isonicotinohydrazide $(30 \mathrm{mg} ; 0.1094 \mathrm{mmol})$ was dissolved in ethanol $(10 \mathrm{~mL}$; solution $\mathrm{A})$. The $\mathrm{FeCl}_{3} .6 \mathrm{H}_{2} \mathrm{O}$ metal $(14.61 \mathrm{mg} ; 0.0540 \mathrm{mmol})$ which has been dissolved in ethanol $(20 \mathrm{~mL}$; solution B), and then it was dripped slowly into solution A. The dropping process was performed constantly and at low heating. Furthermore, the reflux was performed for 5 hours at $\pm 75{ }^{\circ} \mathrm{C}$ and stirred using a magnetic stirrer then the reflux results were filtered and the residue obtained was dried (Zheng et al., 2008; Ruswanto et al., 2018; Ruswanto et al., 2019).

\section{The Purity Test of The Complex}

The purity test of the synthesis results was carried out by analysis of the determination of the melting point by using a modified Melting Point Apparatus. Direct observation of the melting point is done when the compound starts to melt until it melts completely (Ruswanto et al., 2019).

\section{UV-Vis Spectrophotometry}

Samples and standards were dissolved in DMSO with concentrations of $10^{-2} \mathrm{M}$ to $10^{-4}$ $\mathrm{M}$, and then the electronic spectrum was measured with UV-Vis spectrophotometry. Electronic spectrum measurements were performed at 200-800 nm. Uptake was observed at absorbance which corresponds to maximum wavelengths using UV-Vis (Mardianingrum et al., 2020).

\section{Infrared Spectrophotometry}

The $\mathrm{KBr}$ powder was weighed as much as $15 \mathrm{mg}$, while for samples of about 5$10 \%$ of $\mathrm{KBr}$, then crushed on a mortar until smooth and homogeneous, then put sufficiently into a pelletizer that has been cleaned and dried with chloroform. After finishing, the pelletizer is opened slowly, and the pellet that has been formed must be transparent. Each sample pellet that has been prepared is ready to be measured in the region of wave number 4400-400 cm-1 (Ruswanto et al., 2018). 


\section{Molecular Docking}

The docking process was performed using AutodockTools-1.5.6 software between the Fe(III) N'-(4-Chlorobenzoyl) isonicotinohydrazide ligand with the Enoyl-Acyl Carrier Protein Reductase enzyme in Mycobacterium Tuberculosis (PDB code 2X23) through several stages.

\section{Ligand and Receptors Preparation}

Free ligand and complex structures were drawn in a 2-dimensional form. Then, they were done geometry optimization using Marvin Sketch 5.2 software. The ligand was initially protonated at $\mathrm{pH}$ 7.4. The protonation was performed to adjust the $\mathrm{pH}$ condition of blood in the human body. Then, the conformation was performed to get the most stable molecular position to interact with the active site of the enzyme. The file was saved in .mrv and .pdb format for the docking process (Endah et al., 2018). The enzyme preparation was performed using the AutodockTools-1.5.6 software to remove water molecules and the addition of hydrogen atoms.

\section{The Validation of Docking Method}

Method validation was done by redocking native ligand (TCU) which was in 2X23. The parameter for method validation was the root mean square deviation (RMSD) value. The docking method was declared valid if the RMSD value $\leq 2$. But if the RMSD value $\geq 2$, it means the method used cannot be trusted (Agistia et al., 2013; Endah et al., 2018).

\section{Analysis of Enzyme Target}

Analysis of the enzyme target was performed by looking at the 2 X23 GDP protein profile on the website https://www.ebi.ac.uk/pdbsum/. The results of the enzyme target analysis were used to see that the enzyme was good by seeing the Ramachandran plot (Ruswanto et al., 2018).

\section{Docking Ligands Against Target Receptors}

The docking process is done using AutodockTools-1.5.6 software. The ligand docking process is done using parameters used in the docking validation process. From the docking process can be obtained binding affinity $(\Delta G)$ of each docking ligand. To see the interaction between the ligand and the active site of the receptor from the docking results, the software Discovery Studio version 16.1 (Pal et al., 2019).

\section{Visualization of Docking Results}

Visualization of docking results was performed using Discovery Studio version 16.1 software by seeing the interaction between ligands and amino acid residues on the enzyme target in 2D and 3D forms.

\section{Prediction of ADME and Toxicity}

To find out about the ADME parameters and toxicity done through the PreADMET program, which was accessed at https://preadmet.bmdrc.org/. The first, the structure was converted in the molfile format (*.mol) and the PreADMET program will automatically calculate the predicted absorption for Caco-2 cells, HIA (Human Intestinal Absorption), plasma protein binding (PPB) and its toxicity parameters through the amest test (Ruswanto et al., 2017).

\section{RESULTS AND DISCUSSION Synthesis of the $\mathrm{Fe}$ (III)N'-(4-Chlorobenzoyl) isonicotinohydrazide Complex \\ Synthesis of the Fe (III) N '- (4-} Chlorobenzoyl) isonicotinohydrazide complex has occurred through the reaction of coordinate covalent bonds between the metal ion Fe (III) and the N'-(4-Chloro benzoyl)isonicotinohydrazide compound. The solvent used in the process of synthesis of complex compounds was ethanol. Ethanol was chosen because the compound N '- (4-Chloro benzoyl)isonicotinohydrazide has been good solubility in ethanol.

The Complex formation was performed by the reflux method for 5 hours at $\pm 75{ }^{\circ} \mathrm{C}$ while stirring using a magnetic stirrer. The N'-(4-Chlorobenzoyl)isonicotinohydrazide as much as $30 \mathrm{mg}(0.1094 \mathrm{mmol})$ and $\mathrm{FeCl}_{3} \cdot 6 \mathrm{H}_{2} \mathrm{O}$ as much as $14.61 \mathrm{mg}(0.054$ $\mathrm{mmol}$ ). The method used in the reaction was the reflux method, where this method would be able to maintain stability so that complex synthesis reactions were performed even in hot conditions so that the reactant moles and products were maintained (Ningtyas, 2016). The use of $\pm 75{ }^{\circ} \mathrm{C}$ temperature and stirring using a magnetic stirrer which aimed to accelerate and optimize the synthesis reaction process. Increasing the temperature and stirring would increase the kinetic energy to collide with each other, so the chances of a 
reaction would be even greater and faster (Dharmayanti, 2015; Goeswin, 2012).

After the reflux was finished, the reflux results were evaporated in an electric water bath at $60{ }^{\circ} \mathrm{C}$ so that the remaining solvent resulting from the synthesis evaporates. After that, it was allowed to stand until the dry residue was weighed, and a complex compound of $38.1 \mathrm{mg}$ was obtained. The synthesis results obtained the brown powder, odorless, and soluble in ethanol.

\section{Purity Test}

The purity test aimed to ensure that the compound produced was a new compound. Compounds were said to be pure when the melting distance was $\leq 2{ }^{\circ} \mathrm{C}$ (Ritmaleni, 2006). The melting distance data were listed in Table 1. The difference in the melting distance between the results of the synthesis with the comparison shows that the new compound has been successfully formed.

Table 1. The melting distance results

\begin{tabular}{clc}
\hline No. & \multicolumn{1}{c}{ Compound } & $\begin{array}{c}\text { Melting } \\
\text { Distance }\left({ }^{\circ} \mathbf{C}\right)\end{array}$ \\
\hline 1. & $\mathrm{FeCl}_{3} \cdot 6 \mathrm{H}_{2} \mathrm{O}$ & $37.00-39.00$ \\
2. & $\mathrm{~N}^{\prime}-(4$ Chlorobenzoyl) & $199.00-201.00$ \\
& isonicotinohydrazide & \\
& Fe(III)N'-(4- & $196.00-198.00$ \\
3. & Chlorobenzoyl & \\
& Isonicotinohydrazide & \\
\hline
\end{tabular}

\section{Characterization and Identification of The Complex}

Characterization and identification of the complex were performed using the UV-Vis Spectrophotometry and Infrared Spectrophotometry methods.

The first identification and characterization were using UV-Vis spectrophotometry which aims to determine the existence of a shift in the maximum wavelength of the synthesized compound and be compared with the maximum wavelength of the comparison compound. Based on the results of wavelength measurements using UVVis spectrophotometry, the maximum wavelengths obtained were shown in Table 2.

Based on Table 2 showed that there was a difference in the maximum wavelength between the ligand with the complex compound $\mathrm{Fe}$ (III) N'-(4-Chlorobenzoyl) isonicotinohydrazide, where the maximum wavelengths were respectively $272.0 \mathrm{~nm}$ and $261.0 \mathrm{~nm}$. The difference in maximum wavelength indicated that the complex compound $\mathrm{Fe}$ (III) N'-(4-Chlorobenzoyl) isonicotinohydrazide has been formed.

The maximum wavelength of the complex compound $\mathrm{Fe}$ (III) N'-(4Chlorobenzoyl)isonicotinohydrazide undergoes a shift in the absorption band toward shorter wavelengths or the presence of blue shift or hypochromic was detected. The maximum wavelength shift was influenced by the transfer of charge from the metal to the ligand and was also influenced by the polarity of the solvent (Ningtyas, 2016; Hastuti, 2017).

The next step is to determine the electronic spectrum to find out the electronic transition that occurs in the synthesis complex and the amount of transition energy needed for complex division. The magnitude of the maximum wavelength shift $(\lambda \max )$, absorbance (A) of molar absorptivity $(\varepsilon)$ and the value of $10 \mathrm{Dq}$ of the complex compound $\mathrm{Fe}$ (III)N'-(4-Chlorobenzoy)

isonicotinohydrazide can be seen in Table 3 .

Based on Table 3, it could be seen that the electronic spectrum of the compound $\mathrm{Fe}$ (III) N'-(4-Chlorobenzoyl) isonicotino hydrazide showed only one absorption band at a wavelength of $261.0 \mathrm{~nm}\left(38314.18 \mathrm{~cm}^{-1}\right)$ and the molar absorptivity value (molar) $\varepsilon$ equal to 1282.57 L. mol ${ }^{-1} \cdot \mathrm{cm}^{-1}$. This allows a charge transfer transition to occur (Borde, 2015). While the value of $10 \mathrm{Dq}$ in the $\mathrm{Fe}$ (III) N'-(4Chlorobenzoyl) isonicotinohydrazide complex was $458.411 \mathrm{KJ}^{\mathrm{mol}}{ }^{-1}$. This $10 \mathrm{Dq}$ value was the amount of transition energy needed for complex division (Ruswanto et al., 2018).

The next characterization was using infrared spectrophotometry which aimed to determine the functional groups and types of bonds found in the complex compound Fe (III) $\mathrm{N}$ '-(4-Chlorobenzoyl) isonicotinohydrazide so that the bond structure of the complex compound could be predicted. FTIR characterization was performed at wavenumbers $4400-400 \mathrm{~cm}^{-1}$. Distinctive spectra of complex compounds, especially in the fingerprint area that characterizes a complex so that it could be predicted whether complex compounds have been formed or not (Dharmayanti, 2015). The infrared spectrum data were shown in Figures 1 and 2, and Table 4. 
Tabel 2. The UV-Vis spectrums

\begin{tabular}{|c|c|c|}
\hline Compound & $\mathbf{A}$ & $\lambda_{\text {maks }}(\mathbf{n m})$ \\
\hline \multirow{3}{*}{$\mathrm{FeCl}_{3} \cdot 6 \mathrm{H}_{2} \mathrm{O}$} & 3.611 & 363.3 \\
\hline & 3.574 & 361.8 \\
\hline & 3.877 & 361.6 \\
\hline \multirow[t]{2}{*}{ Mean } & 3.687 & 362.3 \\
\hline & 2.348 & 272.0 \\
\hline \multirow{2}{*}{ N'-(4-Chlorobenzoyl) isonicotinohydrazide) } & 2.326 & 272.0 \\
\hline & 2.333 & 272.0 \\
\hline Mean & 2.335 & 272.0 \\
\hline \multirow{3}{*}{ Fe(III)N'-(4-Chlorobenzoyl) isonicotinohydrazide } & 1.360 & 261.1 \\
\hline & 1.445 & 261.1 \\
\hline & 1.391 & 260.9 \\
\hline Mean & 1.398 & 261.0 \\
\hline
\end{tabular}

Tabel 3. Electronic spectrum results

\begin{tabular}{|c|c|c|c|c|c|c|c|}
\hline No. & Compound & $\begin{array}{c}\text { Mr } \\
(\mathrm{g} / \mathrm{mol})\end{array}$ & $\begin{array}{l}\lambda_{\text {maks }} \\
(\mathrm{nm})\end{array}$ & $v\left(\mathrm{~cm}^{-1}\right)$ & $\mathbf{A}$ & $\varepsilon\left(\mathrm{L} \cdot \mathrm{mol}^{-1} \mathrm{~cm}^{-1}\right)$ & 10 Dq $\left(\mathrm{KJJmol}^{-1}\right)$ \\
\hline 1. & $\mathrm{FeCl}_{3} \cdot 6 \mathrm{H}_{2} \mathrm{O}$ & 270.30 & 362.3 & 27601.43 & 3.687 & 2772.18 & 330.238 \\
\hline 2. & $\begin{array}{l}\text { Fe(III)N'-(4- } \\
\text { Chlorobenzoyl) } \\
\text { isonicotinohydrazide }\end{array}$ & 330.15 & 261.0 & 38314.18 & 1.398 & 1282.57 & 458.411 \\
\hline
\end{tabular}

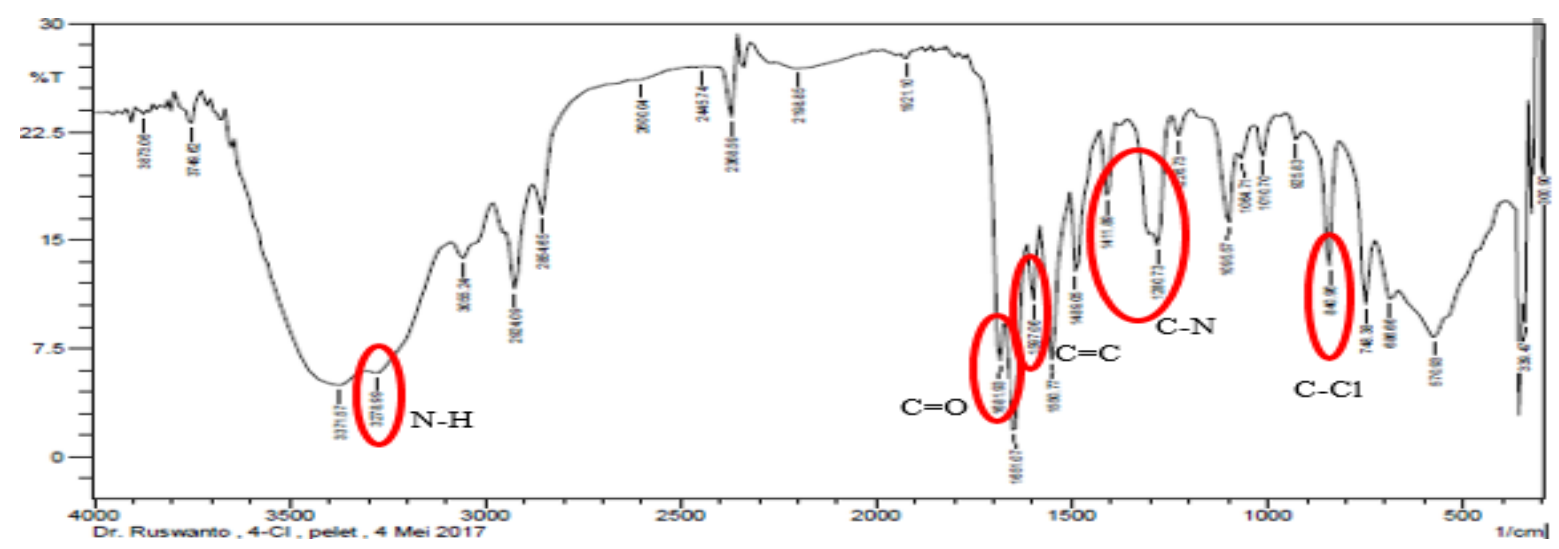

Figure 1. The infra red spectrum of N'-(4-Chlorobenzoyl) isonicotinohydrazide

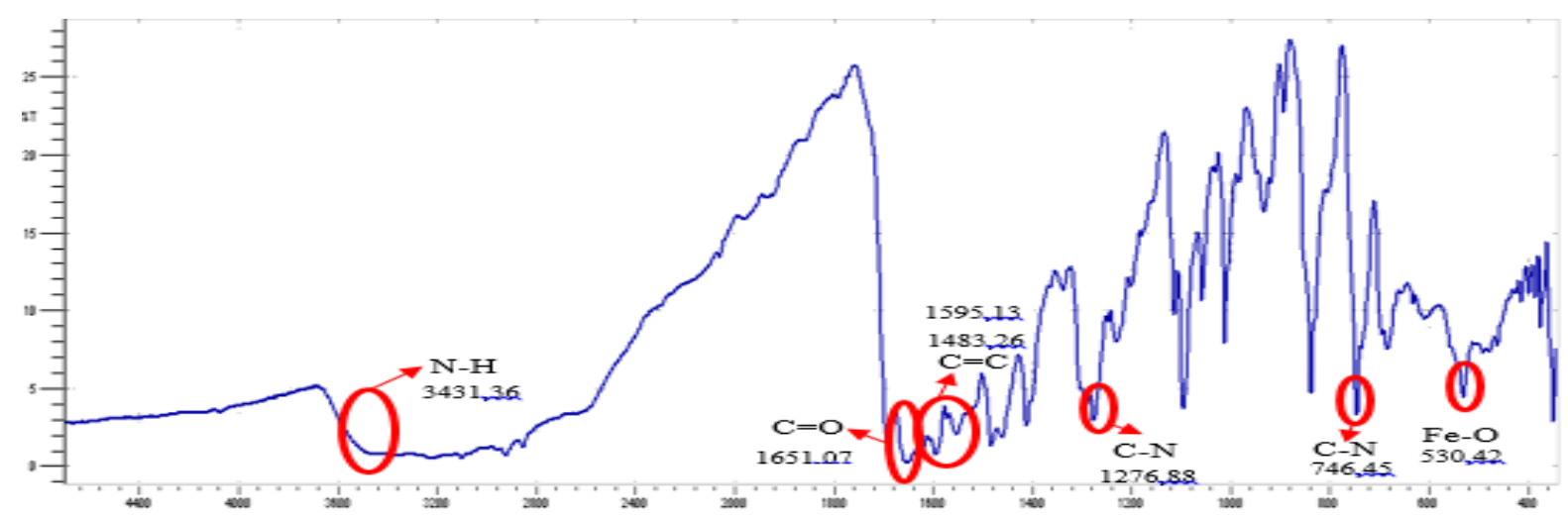

Figure 2. The infra red spectrum of the complex 
Table 4. The IR spectrum value of N'-(4-Chlorobenzoyl)isonicotinohydrazidedan and Fe(III)N'-(4-Chlorobenzoyl)isonicotinohydrazide Complex

\begin{tabular}{cccc}
\hline & & $\boldsymbol{v}\left(\mathbf{c m}^{-\mathbf{1}}\right)$ & \\
\cline { 3 - 4 } No. & $\begin{array}{c}\text { Functional } \\
\text { group }\end{array}$ & $\begin{array}{c}\text { (N'-(4-Chlorobenzoyl)) } \\
\text { isonicotinohydrazide }\end{array}$ & $\begin{array}{c}\text { Fe(III)(N'-(4-Chlorobenzoyl)) } \\
\text { isonicotinohydrazide complex }\end{array}$ \\
\hline 1. & $\mathrm{~N}-\mathrm{H}$ & 3278.99 & 3431.36 \\
2. & $\mathrm{C}=\mathrm{O}$ & 1681.93 & 1651.07 \\
3. & $\mathrm{C}=\mathrm{C}$ & 1597.6 & 1483.26 \\
& aromatic & 1095.57 & 1595.13 \\
4. & $\mathrm{C}-\mathrm{N}$ & 1226.73 & 1276.88 \\
5. & $\mathrm{C}-\mathrm{Cl}$ & 745.35 & 746.45 \\
7. & $\mathrm{Fe}-\mathrm{O}$ & - & 530.42 \\
\hline
\end{tabular}

In infrared spectra, functional groups were identified such as a stretched $\mathrm{NH}$ group in the region of wave number $3431.36 \mathrm{~cm}^{-1}$, where $\mathrm{NH}$ groups could cause hydrogen bonds to form so that the wavenumber and absorption it produces is high (Coates, 2000; Ruswanto et al., 2018 ). Theoretically, the vibration absorption of $\mathrm{C}=\mathrm{O}$ could occur in the region of wave numbers $1800-1650 \mathrm{~cm}^{-1}$ (Widata, 2018). Absorption of $\mathrm{C}=\mathrm{O}$ complex compounds was in the region of $1651.07 \mathrm{~cm}^{-1}$, this wave number was slightly lower because of the mesomeric effect (delocalization of electrons $\pi$ on bonds) so that the vibrational frequency decreases (Ruswanto et al., 2018). The aromatic group was strengthened by the absorption in the region of $1595.13 \mathrm{~cm}^{-1}$ and $1483.26 \mathrm{~cm}^{-1}$ which is the stretching vibration of the $\mathrm{C}=\mathrm{C}$ bond. This was consistent with the literature, which states that the vibration absorption of $\mathrm{C}=\mathrm{C}$ was in the area of 1600$1475 \mathrm{~cm}^{-1}$ (Kusyanto, 2017; Sastrohamidjojo, 2001). Vibration uptake in the region of $1276.88 \mathrm{~cm}^{-1}$ was stretching vibration absorption from $\mathrm{C}-\mathrm{N}$ bonds, and this was in accordance with the literature which states that the absorption of $\mathrm{C}-\mathrm{N}$ bond vibrations was in the wavenumber 1340-1250 $\mathrm{cm}^{-1}$ (Coates, 2000). The $\mathrm{C}-\mathrm{Cl}$ stretching vibration absorption is theoretically in the region of the wavenumber 800-700 $\mathrm{cm}^{-1}$ (Coates, 2000). Based on the analysis results of $\mathrm{C}-\mathrm{Cl}$ vibration absorption of complex compounds found in the region of $746.45 \mathrm{~cm}^{-1}$. Based on the literature, the vibration absorption of the $\mathrm{O}$ group from ligands with metals would appear at

wavenumbers $600-400 \mathrm{~cm}^{-1}$. The results of the analysis of $\mathrm{Fe}-\mathrm{O}$ vibration absorption from ligands $\quad \mathrm{N}$-(4-Chlorobenzoyl)isonicotino hydrazide appeared in the region of $530.42 \mathrm{~cm}^{-}$ ${ }^{1}$ (Nakamoto, 1978; Setyawati, 2010). A shift in the wavenumber of the $\mathrm{Fe}-\mathrm{O}$ bond indicated that the complex compound synthesized has formed. Predictions of bonds that occured between ligands and metals were shown in Figure 3.

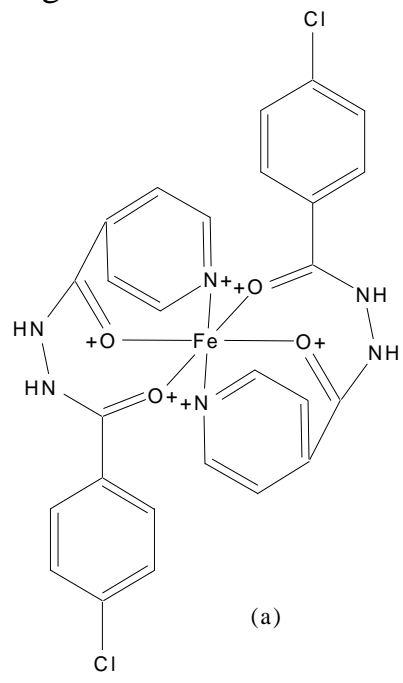

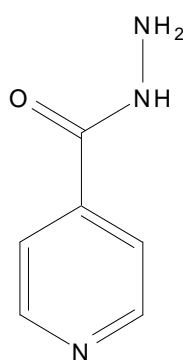

(b)

Figure 3. The structure complex prediction (a) and isoniazid (b).

\section{Molecular Docking}

The docking process was performed using AutodockTools-1.5.6 software between $\mathrm{Fe}$ (III) N'-(4-Chlorobenzoyl)isonicotinohydrazide with enzyme target (PDB code 2X23) through several stages. 


\section{The Ligand and Receptors Preparation}

Ligand preparation was performed using Marvin Sketch 5.2 software. Then geometry optimization was done by protonation at $\mathrm{pH}$ 7.4. This aims to adjust the $\mathrm{pH}$ condition of blood in the human body because the docking process mimics the reactions that occur in the body. Whereas the enzyme preparation was performed using the AutodockTools-1.5.6 software to remove water and add hydrogen atoms (Agistia, 2013; Rachmania, 2018).

\section{The Validation of Docking Method}

The parameter used for this validation was RMSD (Root Mean Square Deviation). The docking method was said to be valid if the RMSD value $\leq 2$. The smaller the RMSD value indicates that the predicted ligand pose was getting better because it approached the native conformation (Hawkins, 2008; Agistia, 2013). The results of docking validation could be seen in Table 5 .

Table 5. The docking validation results

\begin{tabular}{|c|c|c|c|c|c|}
\hline \multirow{2}{*}{$\begin{array}{l}\text { Code } \\
\text { PDB }\end{array}$} & \multicolumn{3}{|c|}{ Grid Box } & \multirow{2}{*}{$\begin{array}{c}\text { RMSD } \\
(\AA)\end{array}$} & \multirow{2}{*}{$\begin{array}{c}\text { Binding Affinity } \\
\text { (kcal/mol) }\end{array}$} \\
\hline & $\mathbf{X}$ & $\mathbf{y}$ & $\mathbf{z}$ & & \\
\hline $2 X 23$ & -19.024 & -5.263 & -29.471 & 1.52 & -4.86 \\
\hline
\end{tabular}

Based on Table 5, the RMSD value for GDP code 2 X23 was 1.52 , the value was $<2$ so that this method could be trusted for use on test ligand.

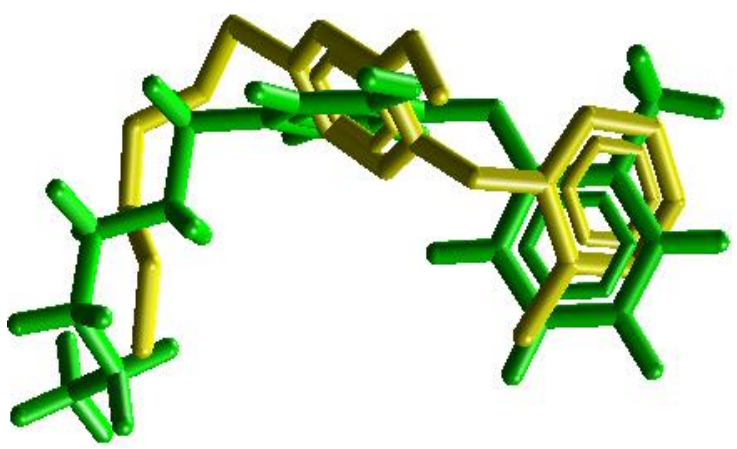

Figure 4. The overlay between native ligand (green) and re-docking (yellow)

\section{Analysis of Enzyme Target}

Enzyme target analysis was performed on validated receptors or proteins in the docking validation process. Analysis of the target receptor or protein aimed to determine the status of the 3D structure of a protein from X-ray crystallography or NMR, through the Ramachandran plot. The enzyme structure was stated to be good if the number of residual plots in most favored regions was more than $50 \%$ and in disallowed regions was less than 15\% (Ruswanto et al., 2018; Amelia, 2013).

Based on observations (Figure 5 and Table 6) receptor or target protein (PDB code 2X23) has a good protein structure because the residual plots in most favored regions are more than $50 \%$, namely $92.1 \%$ and in disallowed regions less than $15 \%$, which is $1 \%$.

\section{The Docking of Complex compound}

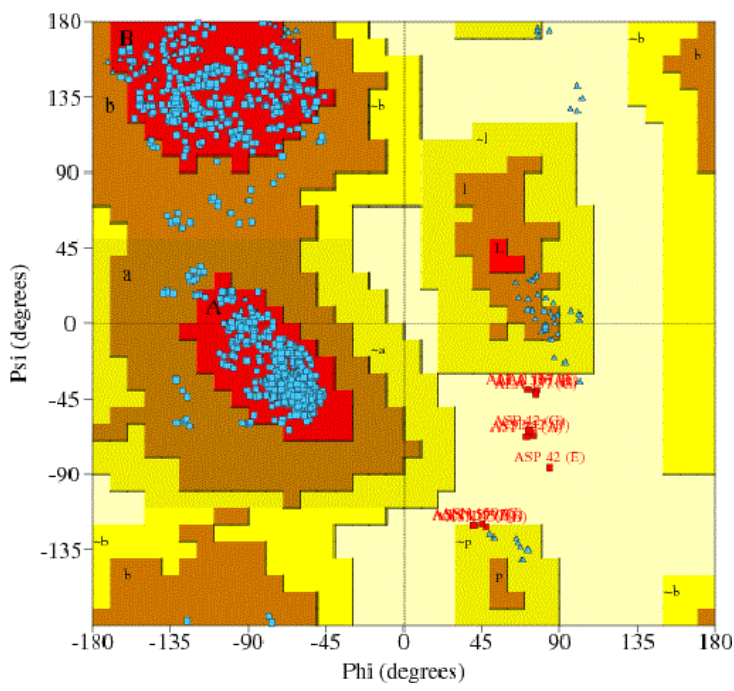

Figure 5. The Ramachandran plot of enzyme target (code PDB 2X23)

The next step was docking the compound $\mathrm{Fe}$ (III) N'-(4-Chlorobenzoyl) isonicotinohydrazide, and the comparison compound was N'-(4-Chlorobenzoyl) isonicotinohydrazide against enzyme with the code PDB 2X23. The docking results were shown in Table 6. 
Table 6. Ramachandran plot statistics

\begin{tabular}{|c|c|c|}
\hline Parameters & No. of Residues & $\%$-tage \\
\hline Most favoured regions & 829 & $92.1 \%$ \\
\hline Additional allowed regions $[\mathrm{a}, \mathrm{b}, \mathrm{l}, \mathrm{p}]$ & 59 & $6.6 \%$ \\
\hline Generously allowed regions $[\sim a, \sim b, \sim 1, \sim p]$ & 3 & $0.3 \%$ \\
\hline Disallowed regions $\quad[\mathrm{XX}]$ & 9 & $1.0 \% *$ \\
\hline Non-glycine and non-proline residues & 900 & $100 \%$ \\
\hline End-residues (excl. Gly and Pro) & 8 & \\
\hline Glycine residues & 112 & \\
\hline Proline residues & 52 & \\
\hline Total number of residues & 1072 & \\
\hline
\end{tabular}

Table 7. The docking results

\begin{tabular}{lcc}
\hline \multicolumn{1}{c}{ Compound } & $\begin{array}{c}\text { Binding Affinity } \\
(\mathbf{k c a l} / \mathbf{m o l})\end{array}$ & $\begin{array}{c}\text { Inhibition Constant } \\
(\boldsymbol{\mu M} \mathbf{M})\end{array}$ \\
\hline Native ligand & -4.86 & 273.25 \\
N'-(4-Chlorobenzoyl)isonicotinohydrazide & -6.35 & 22.11 \\
Fe(III)(N'-(4-Chlorobenzoyl))isonicotinohydrazide & -9.80 & 0.06529 \\
\hline
\end{tabular}

Based on the docking results (Table 7) obtained for Mycobacterium tuberculosis, the value of Gibbs $(\Delta \mathrm{G}) /$ binding affinity $(-9.80$ $\mathrm{kcal} / \mathrm{mol}$ ) and inhibition constant values $(0.06529 \mu \mathrm{M})$ of the complex compound $\mathrm{Fe}$ (III) N'-(4-Chlorobenzoyl)isonicotinohydrazide was lower than the comparative compounds. So it could be said that the complex compound Fe (III) N'-(4-Chloro benzoyl)isonicotinohydra-zide has a better and more stable interaction compared to the comparison compound.

\section{Visualization of Docking Results}

The docking results were visualized to find out the interaction between the ligand and the amino acid residues of the enzyme. Enzyme-ligand interactions could be seen in Table 7. Based on Table 7, it could be seen that the interaction of the complex Fe (III) $\mathrm{N}$ '(4-Chlorobenzoyl) isonicotinohydrazide with amino acid residues through hydrophobic bonds and hydrogen bonds. Hydrophobic bonds in complex compounds interact with 20 amino acids namely Gly96, Ser94, Ser123, Met98, Met103, Ile202, Val203, Met232, Ile194, Leu218, Thr196, Ile21, Met147, Asp148, Gly14, Ser20, Ile95, Ile202, Val203, Met232, Ile194, Leu218, Thr196, Ile21, Met147, Asp148, Gly14, Ser20, Ile95, Lys165, Gly192 and Ph97 . Hydrogen bonds in complex compounds interact with only one amino acid, Tyr158.
ADME and toxicity tests were carried out to determine the pharmacokinetic profile to see the safety of complex compounds. The absorption parameters were predicted based on the ability of the drug absorbed in the intestine (Human Intestinal Absorption) and the ability of permeability in Caco-2 cells. Distribution parameters are predicted based on the attachment to plasma proteins. While the toxicity parameters can be seen from the Ames test. The results of ADME predictions and toxicity can be seen in Table 8 .

Based on ADME predictions (Table 8) isoniazid, compounds before the $\mathrm{N}^{\prime}$-(4Chlorobenzoyl) isonicotinohydrazide complex and Fe (III) N' - (4-Chlorobenzoyl) isonicotinohydrazide complex each had an HIA value of $87,106 \%, 93,058 \%$ and $93,058 \%$, respectively. $100 \%$ The HIA value of all compounds were in the range of $70-100 \%$ which indicated that the compounds could be absorbed well, but it could be seen the acquisition of HIA values of complex compounds was greater than the compound before the complex and its free ligand (isoniazid), which means that the compoundcomplex could be said to have better absorption than the other compounds.

From Table 8, it could be seen that the Caco-2 value of isoniazid, the compound before the complex or complex compound was in the range of 4-70 $\mathrm{nm} / \mathrm{sec}$ which indicated that the permeability of all compounds was moderate. 
Table 7. The interaction between compound with amino acid residue on enzyme target

\begin{tabular}{llc}
\hline \multicolumn{1}{c}{ Compound } & \multicolumn{1}{c}{ Hydrophobic Bonds } & Hydrogen Bond \\
\hline Native ligand & Asp158, Met47, Gln214, Ile215, Met155, Tyr158, & Ile194 \\
& Thr196 dan Gli192 & \\
N'-(4-Chlorobenzoyl) & Pro156, Met147, Asp148, Ala191,Gly192, Pro193, & Ile194 \\
isonicotinohydrazide & Lys165 dan Met199 & \\
& Gly96, Ser94, Ser123, Met98, Met103,Ile202, Val203, & \multirow{2}{*}{ Tyr158 } \\
Fe(III)(N'-(4-Chlorobenzoyl)) & Met232, Ile194, Leu218, Thr196, Ile21, Met147, & \\
isonicotinohydrazide & Asp148, Gly14,Ser20, Ile95, Lys165, Gly192 dan & \\
& Phe97 & \\
\hline
\end{tabular}

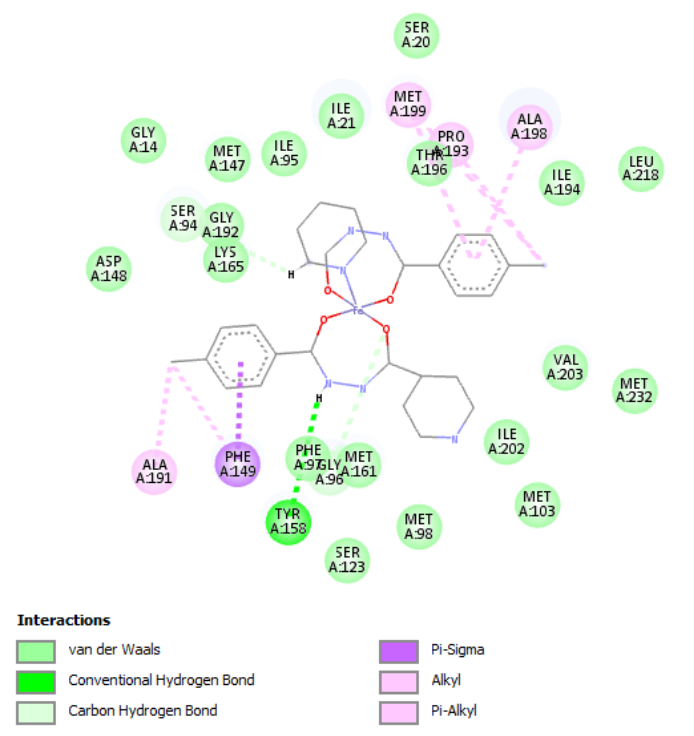

(a)

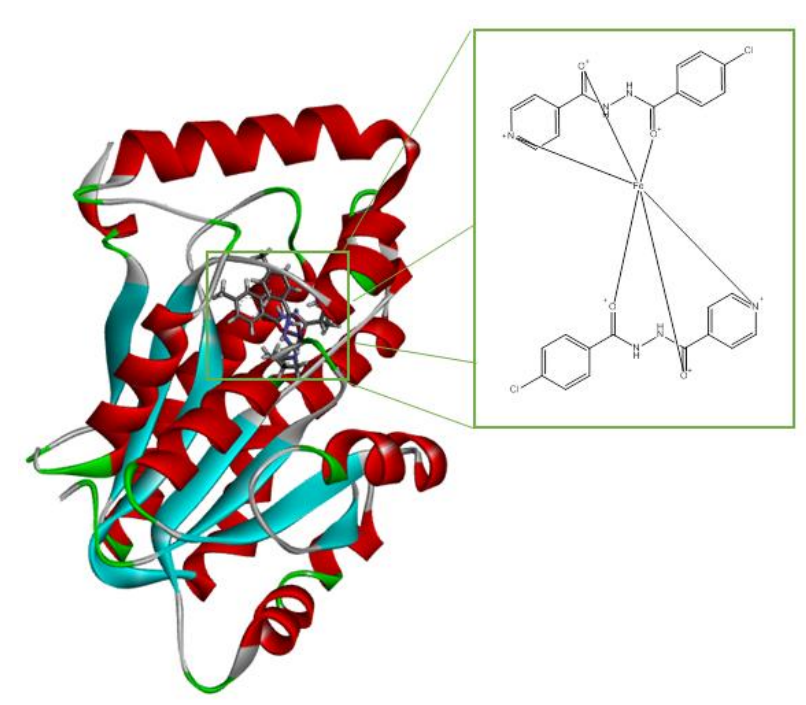

(b)

Figure 6. (a) 2D visualization (b) 3D visualization of complex compound

The ADME and Toxicity Prediction

Table 8. The ADME and toxicity prediction results

\begin{tabular}{|c|c|c|c|c|}
\hline \multirow[t]{2}{*}{ Compound } & \multicolumn{2}{|r|}{ Absorption } & \multirow{2}{*}{$\begin{array}{c}\text { Distribution } \\
\text { PPB }(\%)\end{array}$} & \multirow{2}{*}{$\begin{array}{c}\text { Toxicity } \\
(\text { Ames test })\end{array}$} \\
\hline & $\begin{array}{c}\text { HIA } \\
(\%)\end{array}$ & CaCo-2 (nm/sec) & & \\
\hline Isoniazid & 87.106 & 19.496 & 1.607 & Mutagen \\
\hline N'-(4-Chlorobenzoyl) & & & & Mutagen \\
\hline isonicotinohydrazide & 93.058 & 19.760 & 82.410 & \\
\hline $\mathrm{Fe}(\mathrm{III})\left(\mathrm{N}^{\prime}-(4-\right.$ & & & & Mutagen \\
\hline $\begin{array}{l}\text { Chlorobenzoyl)) } \\
\text { isonicotinohydrazide }\end{array}$ & 100 & 20.590 & 52.159 & \\
\hline
\end{tabular}

The efficacy of a drug was influenced by the binding of plasma proteins, which were generally only drugs in an unbound form that could diffuse through the cell membrane and interact with the receptors. (Nursamsiar, 2016). In Table 8, the complex compounds and their comparative compounds have a weak attachment to plasma proteins, because 
the value of plasma protein binding (PPB) of all compounds $<90 \%$ so that it could be said that the all compounds could be well distributed. But the PPB value of complex compounds was lower $(52.159 \%)$ than the compound before the complex so that it can be said that the distribution of complex compounds was better than the compounds before the complex

The toxicity parameters could be seen from the mutagenic properties of the compounds being tested. Mutagen was a compound that could increase the rate of change or mutation in genes so that it could trigger the development of cancer (Wahyuningrum, 2011). From the prediction of toxicity using the PreADMET program showed that both complex and comparison compounds have mutagen properties. Although mutagenic, this compound could still be applied as a candidate drug with the appropriate dosage (Ruswanto et al., 2018).

\section{CONCLUSION}

Based on the research, it can be concluded that the complex FeIII) $\left(\mathrm{N}^{\prime}\right.$ (4Chlorobenzoyl) isonicotinohydrazide can be synthesized through the reaction between $\mathrm{FeCl}_{3} \cdot 6 \mathrm{H}_{2} \mathrm{O}$ and $\mathrm{N}^{\prime}$ - (4-Chlorobenzoyl) isonicotinohydrazide.

The results of molecular docking showed that the complex $\mathrm{Fe}$ (III) N'-(4Chlorobenzoyl) isonicotinohydrazide could interact with the enzyme Enoyl-Acyl Carrier Protein Reductase on Mycobacterium tuberculosis and were predicted to have a better interaction than isoniazid or $\mathrm{N}^{\prime}$-(4Chlorobenzoyl) isonicotinohydrazide with the acquisition of free energy binding $(\Delta G)$ value of $-9.80 \mathrm{kcal} / \mathrm{mol}$ and inhibition constant $(\mathrm{Ki})$ of $0.06529 \mu \mathrm{M}$.

For further studies, molecular dynamics must observe the stability of interactions between complex compounds and target receptors.

\section{ACKNOWLEDGMENT}

Thank to the Ministry of Research, Technology and Higher Education for PDUPT Grant in 2018 and to STIKes BTH for all laboratory facilities in this study.

\section{REFERENCES}

Agistia DD, Purnomo H, Tegar M, Nugroho AE.
2013. Interaction between active compounds from aegle marmelos correa as anti inflammation agent with COX-1 and COX-2 receptor. Traditional Medicine Journal. 18(2): 80-87.

Ali M, Ahmed M, Hafiz S, Kamal M, Mumtaz M, Hanif M, Khan KM. 2017. Metal complexes of isonicotinylhydrazide and their antitubercular activity. Pak. J. Pharm. Sci. 30(7): 2399-2403.

Amelia F. 2013. Modeling struktur protein vaksin H5N1 HA BTB menggunakan I-Tasser. Sainstek. 7(1): 1-5.

Borde V, Naglolkar B, Shankarwar S, Shankarwar A. 2015. Synthesis and characterization of antimicrobial activities of some transition metal complexes of asymmetrical tetradentate ligands. Research Journal of Chemical Sciences. 5(5): 19-23.

Coates J. 2000. Interpretation of Infrared Spectra, A Practical Approach. Encyclopedia of Analytical Chemistry: 1-23.

Dharmayanti A, Martak F. 2015. Sintesis senyawa aktif kompleks mangan(II) dengan ligan 2(4-nitrofenil)-4,5-difenil-1H-imidazol. Jurnal Sains Dan Seni ITS. 4(2): 52-56.

Endah SRN, Mardianingrum R, Ruswanto. 2018. Identifiksi target reseptor senyawa 10,11dihidroerisodin sebagai kandidat antikanker secara in silico. Jounal of Pharmacopolium. 1(1): 32-36. DOI: http://dx.doi.org/10.36465/jop.v1i1.3 93.

Goeswin A. 2012. Sediaan Farmasi Padat. Bandung: ITB.

Hastuti IW, Brams DW. 2017. Karakterisasi butiran sub mikron nanomaterial karbon batok kelapa dengan variasi waktu pengadukan bahan yang digunakan untuk filtrasi logam Fe dari limbah air selokan mataram berdasarkan uji Uv-Vis, XRD, SEM dan AAS. Jurnal Fisika. 6(4): 308-318.

Hawkins PCD, Warren GL, Skillman AG, Nicholls A. 2008. How to do an evaluation: pitfalls and traps. J Comput Aided Mol Des. 22: 191-192. https://doi.org/10.1007/s10822008-9201-z

Kemenkes RI. (2016). Peraturan Menteri Kesehatan Republik Indonesia No. 67 tentang Penanggulangan Tuberkulosis. 
Jakarta: Kememterian Kesehatan Republik Indonesia.

Kusyanto A, Sugiyarto KH. 2017. Sintesis dan karakterisasi senyawa kompleks besi (III) dengan ligan 1,10-fenantrolin dan anion trifluorometanasulfonat. Jurnal Kimia Dasar. 6(1): 51-58.

Mallikarjuna NM, Keshavayya J, Ravi BN. 2018. Synthesis, spectroscopic characterization, antimicrobial, antitubercular and DNA cleavage studies of 2-(1H-indol-3yldiazenyl)-4,5,6,7-tetrahydro-1,3-

benzothiazole and its metal complexes. Journal of Molecular Structure. 1173: 557-566.

Mardianingrum R, Susanti, Ruswanto R. 2020. Bis(N'-(3-Clorobenzoyl)isonicotinohydrazide)iron(III) Complex. Molbank. 2020(1). M1101.

Mardianingrum R, Ruswanto R, Nurjanah R, Nofianti T, Apriliani AY. 2019. The biology activities of isonicotinohydrazide derivatives as an anti-tuberculosiss candidate the biology activities of isonicotinohydrazide derivatives as an anti-tuberculosis candidate, IOP Conf. Series: Journal of Physics: Conf. Series. 1179(2019): 012181.

Ming XL, Jing Z, Zi LW, Jing PW. 2008. Synthesis, crystal structure and antitumor study of a cobalt (II) complex of the 2acetylpyrazine thiosemicarbazone. $Z$. Naturforsch. 63b: 1-5.

Nakamoto. 1978. Infrared and Raman Spectra of Inorganic and Coordination Compound (Third Edition). New York: John Wiley and Sons, Inc.

Ningtyas AP, Martak F. 2016. Sintesis dan uji toksisitas kompleks kobalt(II) dengan ligan $(6 \mathrm{E})-(\mathrm{N} 2)-((\mathrm{E})-2-(6-a m i n o p i r i d i n-2-$ ilimino)-1,2-difeniletilidin)piridin-2,6diamina. Jurnal Sains Dan Seni ITS. 5(2): 3-7.

Nursamsiar, Toding AT, Awaluddin A. 2016. Studi in silico senyawa turunan analog kalkon dan pirimidin sebagai antiinflamasi: prediksi absorpsi, distribusi dan toksisitas. Pharmacy. 13(1): 92-100.

Pal S, Kumar V, Kundu B, Bhattacharya D, Preethy N, Reddy MP, Talukdar A. 2019. Ligandbased pharmacophore modeling, virtual screening and molecular docking studies for discovery of potential topoisomerase I inhibitor. Computational and Structural Biotechnology Journal. 17(2019): 291$310 . \quad$ https://doi.org/10.1016/ j.csbj.2019.02.006.

Rachmania RA, Haeyanti, Zikriah R, Sultan A. 2018. Studi in silico senyawa alkaloid herba bakung putih (Crinum Asiaticum L.) pada penghambatan enzim siklooksigenase (COX). Jurnal Kimia Valensi. 4(2): 124136.

Ritmaleni, Nurcahyani W. 2006. Sintesis 4-fenil3,4-tetrahidro-indeno [2,1]-pirimidin-2-on (LR-1). Majalah Farmasi Indonesia. 17(3): 149-155.

Ruswanto R, Sarwatiningsih Y, Pratita ATK, Indra, Dewi R. 2019. Synthesis and characterization of Fe ( III ) complex with N'-(3-Nitrobenzoyl) isonicotinohydrazide as an anti-tuberculosis candidate. IOP Conf. Series: Journal of Physics: Conf. Series. 1179(2019): 012136.

Ruswanto R, Mardianingrum R, Lestari T, Nofianti T, Rahayuningsih N. 2019. Synthesis and molecular docking of isonicotinohydrazide derivatives as anti-tuberculosis candidates. Malaysian Journal of Fundamental and Applied Sciences. 15(3): 367-371.

Ruswanto, Wulandari WT, Rahayu S, Mardianingrum R, Hidayati ND. 2020. Studi in silico dan bioaktivitas senyawa turunan N'-benzoylisonicotinohydrazide (4-methyl, 4-cloro dan 3,5-dinitro) pada Mycobacterium tuberculosis (H37Rv), bakteri gram positif serta bakteri gram negatif. Pharmacoscript. 2(2): 118-130.

Ruswanto R, Mardianingrum R, Apriliani AY, Ramadaniah FK, Sarwatiningsih Y, Pratita ATK, Nuryani GS, Rahayuningsih N, Lindaswastuti L, Rahayu SS, Wulandari WT, Lihandini G. 2018. Karakterisasi dan sintesis senyawa kompleks Fe (III) sebagai kandidat anti tuberkulosis. Journal of Pharmacopolium. 1(2): 100-106.

Ruswanto R, Garna IM, Tuslinah L, Mardianingrum R, Lestari T, Nofianti T. 2018. Kuersetin: penghambat uridin 5monofosfat sintase sebagai kandidat antikanker. ALCHEMY Jurnal Penelitian. 14(2): 236-252. https://doi.org/10.20961/ alchemy.14.2.14396.236-254. 
Setyawati H, Murwani IK. 2010. Sintesis dan Karakterisasi Senyawa Kompleks Besi(III)-EDTA. Prosiding Seminar Nasional Sains.

Siswandono, Soekarjdo B. 2016. Kimia Medisinal Edisi 2. Surabaya: Airlangga University Press.

Sousa EHS, Basso LA, Santos DS, Diógenes ICN, Longhinotti E, de França Lopes LG, de Sousa Moreira Í. 2011. Isoniazid metal complex reactivity and insights for a novel anti-tuberculosis drug design. JBIC Journal of Biological Inorganic Chemistry. 17(2): 275-283. doi:10.1007/ s00775-011-0848-x

Suo J, Chang CE, Lin TP, Heifets LB. 1988. Minimal inhibitory concentrations of isoniazid, rifampin, ethambutol, and streptomycin against Mycobacterium tuberculosis strains isolated before treatment of patients in Taiwan. American
Review of Respiratory Disease. 138(4): 999-1001. doi:10.1164/ajrccm/138.4.999 .

Tarallo MB, Urquiola C, Monge A, Costa BP, Ribeiro RR, Filho AJC, Mercader RC, Pavan FR, Leite CQF, Torre MH, Gambino D. 2010. Design of novel iron compounds as potential therapeutic agents against tuberculosis. Journal of Inorganic Biochemistry. Elsevier Inc. 104(11): 1164-1170. doi: 10.1016/j.jinorgbio.2010. 07.005 .

Wahyuningrum R, Wirasutisna KR, Elfahmi, Wibowo MS. 2011. Efek mutagenik ekstrak metanol ampas biji jarak (Jatropha curcas L.) sisa pengolahan bahan bakar nabati (biofuel). Majalah Obat Tradisional. 15(3): 89-93.

WHO. 2018. Global Tuberculosis Report 2018. Geneva. 